\title{
Development Tourism Geographic Information System of Samarinda
}

\author{
Agung Wiyanda \\ Software Engineering Technology, \\ Agriculture Polytechnic of \\ Samarinda, 73151, Indonesia \\ wiyandaa7@gmail.com
}

\author{
Suswanto * \\ Software Engineering Technology, \\ Agriculture Polytechnic of \\ Samarinda, 75242, Indonesia \\ Suswanto.attala@gmail.com \\ *Corresponding Author
}

\author{
F.V Astrolabe Sian Prasetya (i) \\ Geomathic Technology, Agriculture \\ Polytechnic of Samarinda, 75242, \\ Indonesia \\ astrolabesp@samarinda.ac.id
}

Submitted: 2021-10-02; Revised: 2021-10-03; Accepted: 2022-02-28; Published: 2022-03-01

\begin{abstract}
This research is motivated by the low level of dissemination of tourism information in the city of Samarinda. Samarinda is one of the cities with very diverse and interesting tourism potentials to explore. The beauty of the urban area and being one of the cities that is crossed by the largest river in the province of East Kalimantan, namely the Mahakam river, makes it one of the tourist destinations that has its own charm, but unfortunately at this time the tourism places in the city of Samarinda have not been widely publicized due to lack of information. About tourism that is given to the public and there are also some places that have not been or have just been opened to become tourist sites. This study uses spatial data in the form of location coordinates and non-spatial data in the form of attribute data including tourist names, addresses, and types of tours, descriptions and pictures. Making the Samarinda City Tourism Geographic Information System website using the Leaflet API as a base map. The database created using PHPMyAdmin on the Samarinda City Tourism Geographic Information System is based on collecting secondary data on tourism information at the Samarinda City Tourism Office and also collecting primary data by interviewing tourist objects that have not been recorded at the Samarinda City Tourism Office. The system and appearance of the Samarinda City Tourism Geographic Information System website was built with the CodeIgniter 3 framework using Visual Studio Code as a text editor. The results of this study are the Samarinda City Tourism Geographic Information System which provides information on tourist names, addresses, types of tours, location coordinates, descriptions, images and is equipped with search features and also road routes to tourist sites. It is hoped that the Samarinda City Tourism Geographic Information System can provide adequate information about tourism information in the city of Samarinda so as to facilitate the delivery and acceptance to the public, especially prospective tourists.
\end{abstract}

Keywords-Website, Tourists, Lafleat, CodeIgniter, API (Application Program Interface).

\section{INTRODUCTION}

East Kalimantan Province consists of 7 regencies namely Berau, West Kutai, East Kutai, Kutai Kartanegara, Mahakam Ulu, Paser and North Penajam Paser and 3
Cities namely Balikpapan, Bontang and Samarinda. Each City/Regency has various tourism and cultural potentials, tourism and culture of each of these areas has its own characteristics and uniqueness that need to be developed and preserved. One of the cultural potentials in East Kalimantan is in the city of Samarinda. The city of Samarinda has a very interesting tourism potential to explore. The beauty of the urban area and being a city that is crossed by the largest river in East Kalimantan, namely the Mahakam River, makes it one of the tourist destinations that has its own charm, but unfortunately at this time the tourist attractions in Samarinda City have not been widely publicized because there are several new places. Opened as a tourist attraction.

The Web-based Samarinda City regional tourism information system is needed as a means of delivering information to people who want to know tourism places in Samarinda City. This information system is also a form of promotion, where one of the intermediary media is a computer. A Web-based Samarinda City regional tourism information system is needed to attract local and foreign tourists to travel to Samarinda City.

The more tourists visit, the income of the area and the surrounding community will increase. In addition, with the existence of a Web-based tourism information system, tourist objects in the Samarinda City area will be better known by the outside community. Thus, it also motivates local governments to pay more attention to the management of these tourism places.

\section{LITERATURE REVIEW}

\section{A. Study of Literature}

Some of the literature as a guide and reference in this paper:

1. Research conducted by Sihombing, (2020) with the title Dairi Regency Web-Based Tourism Information System is one of the regions in Indonesia that has a good tourism and cultural sector. Various types of tourism such as nature tourism, culture, agro tourism and historical tourism are found in the area. However, the dissemination of information about tourism is still manual. In this case the designer is aware of the rapid advancement of web-based technology. Internet media, especially the web, is one of the tools for individuals and a community in carrying out their daily activities. 
2. Research conducted by Ardhiyani ,Mulyono, Heri (2018) in his journal entitled Analysis and design of a Web-based Tourism Information System as a promotional media in Tebo Regency, namely there is currently no adequate information about tourism objects in Tebo Regency. so there are not many tourists and also the public who know the potential tourist objects. Therefore, this needs to be overcome by promoting and providing information using website-based information media. The purpose of designing this web-based information system is to promote tourism in Tebo Regency. Web-based information systems are media that have elements of text, animated images, and sound. These elements make this media interesting. The research method used is data collection through literature studies, interviews, and observations, as well as analyzing equipment requirements software, building a database with mysql, designing the interface using Macromedia Dreamweaver and PHP.

3. Research conducted by Renaldi R, (2020) with the title Geographic Information System Mapping High Schools / Equivalents in Surakarta City Using Website-Based Javascript Library Leaflets is to design and build a webbased Geographic Information System for the distribution of SMA / SMK in the city of Surakarta by using the Javascript Leaflet Library to display the distribution map of SMA / SMK. This application allows to find the location of schools around the user and provide information about the school profile. It is hoped that this application can help the public in accessing information about the location and profile of schools in the city of Surakarta. The system development uses a linear sequential method (Waterfall) and is made with several components, namely HTML, CSS, Javascript, PHP and mysql. The result of this research is a web-GIS that can display the location of the distribution of schools and school profiles in the city of Surakarta

4. Research conducted by (Kurnia Rezy, (2017) with the title Tourism Development by the Department of Culture and Tourism (DISBUDPAR) of Bukittinggi City to Increase Regional Original Income (PAD) is tourism development carried out by the Bukittinggi City Government in increasing regional original income ( PAD) has been going well, because tourism development carried out by the Government is not only to increase regional income from the tourism sector, but also to increase regional income from other sectors that contribute to regional income.

5. Research conducted by (Amrin N, (2015) with the title Use of Geographic Information Systems Growing Desire For Tourism Travel, namely Referring to the discussion in the previous section the use of web applications based on geographic information systems so far has given good results to promote the importance of information through technology. The reality is that geographic data in the real world comes from a variety of formats. The use of maps to present information is an effective way for tourists to grow their desire to visit tourist sites. The Tourism GIS system can provide map information on the location of attractions and provide information on the shortest route, distance traveled between location A and location B. Geographic information systems are a rapidly growing field enabling the development of applications that manage and use geographic information to combine it with other regional media.

\section{B. Basis Theories}

\section{System}

The word 'system' means 'a collection of components that have an element of connection between one another (Indrajit, R. E. 2015).

\section{Information}

The definition of the word 'information' itself has been internationally agreed upon as 'the result of data processing' which in principle has more value than raw data (Indrajit, R. E. 2015).

\section{Information System}

An information system is a collection of components within a company or organization related to the process of creating and flowing information (Indrajit, R. E. 2015). An information system is a set of hardware, software, brainwave and procedures that are integrally organized to process data into useful information for problem solving and decision making.

4. Geographic Information System (GIS)

a. Definition of Geographic Information System (GIS)

Geographic Information System (GIS) or also known as Geographic Information System (GIS) is a computer-based information system, designed to work using data that has spatial information (spatial efficiency). (Suntoyo, M. 2012)

b. GIS Subsystem

1) Input Data

This subsystem is tasked with collecting and preparing data from spatial and attribute sources. This subsystem is also responsible for converting or transforming the original data into data that can be used by GIS.

\section{2) Output Data}

This sub-system displays or produces output of all or part of the database in both softcopy and hardcopy forms such as: tables, graphs, maps and others.

3) Vector Data

In vector format data, our earth is represented as a mosaic of lines, polygons (areas bounded by lines that start and end at the same point), points (nodes that have labels), and nodes (which are points of intersection). Between two lines

a. Vector Points

Point vectors are simply XY coordinates. Each point is a value of latitude and longitude in a particular spatial reference frame. Can be seen in picture 1 . 
P

\section{9}

Picture. 1. Vector Points

\section{b. Vector Line}

Lines connecting coordinate points basically, in a line, you connect the points in a set order and it becomes a line vector of each turn. Can be seen in picture 2 .



Picture. 2. Vector Line

c. Polygon Vector

When you join a set of vertices (points) in a certain order and close them, this data is now a polygon vector. Can be seen in picture 3 .

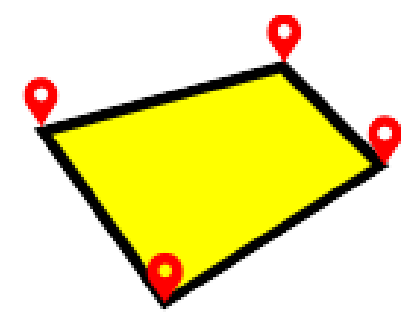

Picture. 3. Polygon Vector

\section{4) Raster Data}

Raster data (also known as grid cells) is data generated from remote sensing systems. In raster data, geographic objects are represented as grid cell structures called pixels (picture elements). In raster data, the resolution (visual definition) depends on the pixel size. In other words, pixel resolution describes the actual size on the earth's surface represented by each pixel in the image. Can be seen in picture 4 .

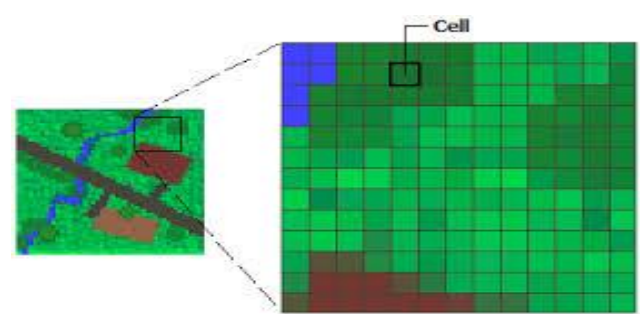

Picture. 4. Raster

The smaller the size of the earth's surface represented by a single cell, the higher the resolution.

5) Data Management

This subsystem organizes both spatial data and attribute data into a database.
6) Data Manipulation and Analysis

Determine the information that can be generated by GIS. In addition, this subsystem also performs data manipulation and modeling to produce the expected information.

\section{Geographical Location}

Geographical location is the location of an area or region seen from the reality on the earth's surface. Based on its geographical location, the Indonesian archipelago is located between the continents of Asia and the continent of Australia, as well as between the Indian Ocean and the Pacific Ocean. Thus, the territory of Indonesia is in a cross position, which has an important meaning in relation to climate and economy. 6. Leaflet

Leaflet is an open-source javascript library for creating interactive maps. This library is very popular because it is mobile friendly, has a small file size and can be extended with plugins or by using only javascript functions. Leaflet.Js can display maps or maps from various sources, such as Google maps, OpenStreetmap, OpenWheatherMap and others. (Susilo, F. D. 2018)

\section{WebGIS}

Web-GIS is a web-based Geographic Information System which consists of several interrelated components. Web-GIS is a combination of mapping graphic design, digital maps with geographic analysis, computer programming, and a database that is interconnected into one part of web design and web mapping (Qolis, et al. 2010). WebGIS is used because in the delivery and display of geographic information systems it is more attractive and presents the actual conditions.

8. System Development Life Cycle Waterfall Model

System Development Life Cycle or better known as SDLC is a general methodology used to develop information systems. SDLC consists of several phases starting from the planning, analysis, design, and implementation to system maintenance phases. This SDLC concept underlies various types of software development models to form a framework for planning and controlling the manufacture of information systems. (Rani Susanto, A. D. 2016)

The Waterfall model is one of the SDLC models that is often used or often referred to as the conventional model or classic life cycle. This model uses a systematic and sequential approach starting from the level of system requirements and then moving on to the stages of analysis, design, coding, testing/verification and maintenance.

\section{Tourism}

The word tourism became popular in Indonesia after the second National Conference on Tourism eke was held in Tretes, East Java (12 to 14 June 1458). PARI means many, many times, round and round, complete while WISATA means journey, traveling. So tourism can be interpreted as a trip that is carried out many times or in circles from one place to another which in English is called the word "tour", while for 
the plural sense of "tourism" the word "tourism" or "tourism" can be used. Tourism limits according to MPRS No. I-II 1960 are as follows:

"Tourism in the modern world is essentially a way to meet human needs in providing spiritual and physical entertainment after some time of work and having the capital to see other areas (domestic tourism) or other countries (foreign tourism)".

Tourism is one of the leading sectors in development to increase national income, absorb labor, and contribute to the country's foreign exchange. Therefore, local governments are expected to take advantage of these opportunities, especially optimizing the potential of natural resources and the diversity of cultures and traditions. (Ambarita, Umagapi, D., \& Arisandy. 2018)

\section{Code Igniter}

It is an open source application in the form of a PHP framework with an MVC (Model, View, Controller) model to build dynamic websites using PHP. CodeIgniter makes it easy for web developers to create web applications quickly and easily compared to building them from scratch. (id.wikipedia.org)

\section{System Usability Scale}

The system usability scale, developed by John Brooke, is a reliable, popular, effective, and inexpensive usability scale that can be used for a global assessment of system usability. The usability scale system has ten question components and five answer choices, ranging from strongly disagree to strongly agree, and has a minimum score of 0 and a maximum of 100. The usability scale system in the original language uses English, but in this paper we use SUS which has been translated into in Indonesian. (Edi Susilo, F. D. 2018).

\section{GPS Essentials}

GPS (Global Positioning System) Essentials is a GPS application on Smartphones with various GPS functions in it which can be obtained for free or paid through the Market or Google Play Store. GPS Essentials is a complex application, most of the applications take care of one particular thing and they do it well. GPS Essentials stores information in a database on your SD card and in app preferences. The database stores all objects relevant for navigation such as waypoints, tracks, routes, tags and messages. (Schollmeyer, 2015)

Find and determine coordinates with GPS Essentials.

a. On the GPS Essentials home screen, select Waypoints. Can be seen in picture 5 .

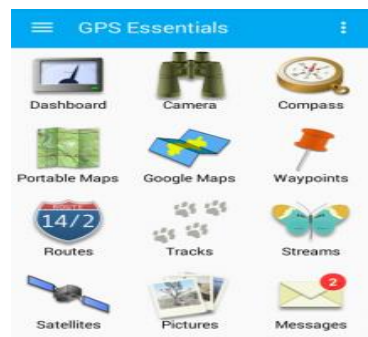

Picture. 5. GPS Essentials App b. Make sure you with GPS Essentials on your Android Smartphone are standing at the point where the coordinates will be taken. Then select the + button as shown below. Can be seen in picture 6 .

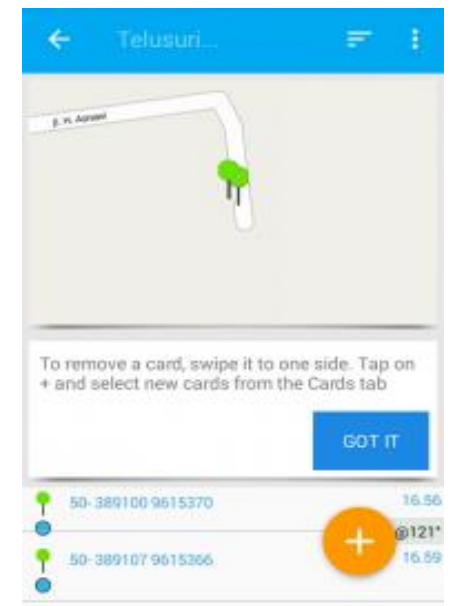

Picture. 6. Determine the Coordinates

c. Observe the number of satellites used and accuracy. The smaller the accuracy, the better the result. If you are satisfied with the existing accuracy, immediately select the Create button. Can be seen in picture 7 .

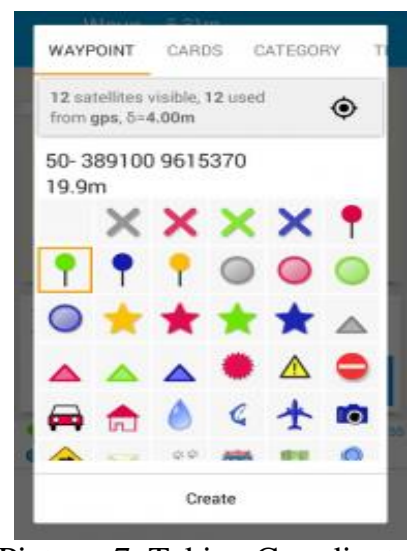

Picture. 7. Taking Coordinates

\section{RESEARCH METHODS}

\section{A. Research Time and Place}

\section{Research Time}

The implementation time of this research will be carried out for 6 month (January - June 2021)

\section{Research Location}

This research was carried out at the Samarinda City Tourism Office and tourist sites scattered in the Samarinda City area.

\section{B. Research Tools and Materials}

1. The tools used for this research

a. GPS Essentials is used to take the coordinates of the location of the Tourism location.

b. Laptop serves to create data and systems.

c. Mobile camera serves to take pictures of tourist 
locations for data.

d. Motorized vehicles are used to take points.

e. Software (Xampp, Leaflet, MySQL, Microsoft Word, Visual Studio Code, Star UML, Code Igniter), serves to create Geographic Information Systems (Tourism Locations).

2. Materials used for research

a. Tourist location data, needed for research and system development.

b. Stationery, needed to record various information related to research.

\section{Research Procedure}

This research uses the System Development Life Cycle (SDLC) method which is a pattern taken to develop a software system, which consists of stages. System requirements (System requirements), Data Analysis (Data Analysis), Design (Design), Programming, Testing (Testing). Can be seen in picture 8 .

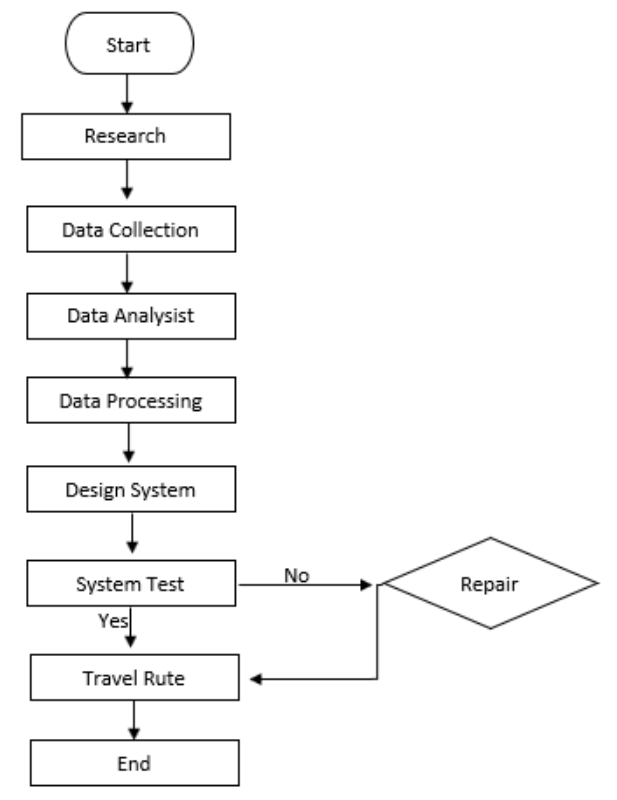

Picture. 8. Research Flowchart

\section{Database Design}

\section{User Table}

The user table has a function to process user data. This table consists of 4 fields, namely the id_user field for id, the name field for the user name, the user_name field for the login username and the password field for the login password. Can be seen in table 1 .

Table 1. User

\begin{tabular}{ccc}
\hline \hline Field Name & Data Type & Length \\
\hline id_user & int & 11 \\
name & varchar & 255 \\
user_name & varchar & 255 \\
password & varchar & 255 \\
\hline \hline
\end{tabular}

\section{Tourism Table}

This table consists of 9 fields, namely the id_location field for the location id, the id_tipe_wisata field for connecting with the tourist_type entity, the nama_location_wisata field for the name of the tourist location, the address field for the location address, the image field for the location image, the description field for the location description, the latitude field for latitude. Location, and the longitude field for the location longitude can be seen in table 2 .

Table 2. Tourist

\begin{tabular}{ccc}
\hline \hline Field Name & $\begin{array}{c}\text { Data } \\
\text { Type }\end{array}$ & Length \\
\hline id_tourist & int & 11 \\
name_tourist & varchar & 255 \\
user_name & varchar & 255 \\
type_tourist & varchar & 255 \\
address & varchar & 255 \\
latitude & varchar & 255 \\
longitude & varchar & 255 \\
description & text & \\
picture & text & \\
\hline \hline
\end{tabular}

E. Application Design

\section{Home Display Menu}

On the initial page design, users can see the introduction to the website and see the home menu and maps. Can be seen in picture 9 .

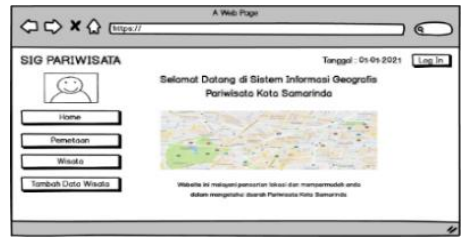

Picture. 9. Home Display

\section{Mapping View}

In the mapping menu, users can press objects on maps and display selected tourist information. Can be seen in picture 10 .

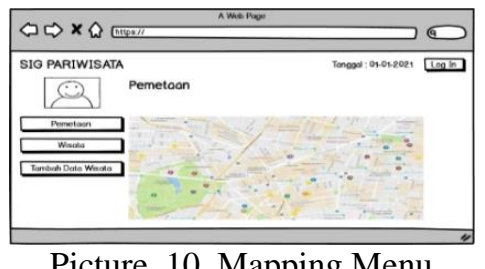

\section{Login Display}

In the login plan, it is created for admins. Where when the admin wants to add information related to Tourism Locations, the admin must login by entering the username and password first. Can be seen in picture11.

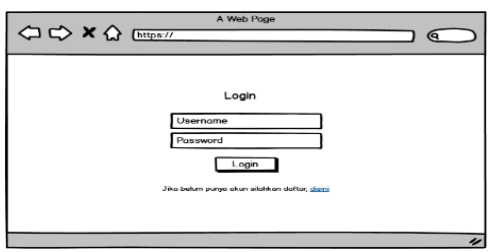

Picture. 11. Menu Login 


\section{Tourist Data Table Display}

In the tourist data table menu, we can find out comprehensive information from tourist locations in Samarinda City. Can be seen in picture 12.



Picture. 12.Display Menu Login

\section{Display Add Tourist Data}

In this menu the admin can add the latest tourist attractions that were previously unknown to many people. Can be seen in picture 13 .



Picture. 13. Add Tourist Data

\section{F. Response Rest - API (Application Programming Interface)}

Based on the use case analysis, ERD and database design, it can be concluded that the entire API method is the focus of android system development. Can be seen in table 3

Table 3. Responses API

\begin{tabular}{cccc}
\hline \hline Process & Method & URL & Entity \\
\hline $\begin{array}{c}\text { Create and } \\
\text { display }\end{array}$ & POST & $\begin{array}{c}\text { api/pari } \\
\text { wisata }\end{array}$ & $\begin{array}{c}\text { tbl_pariw } \\
\text { isata }\end{array}$ \\
$\begin{array}{c}\text { Geurist data } \\
\text { display }\end{array}$ & GET & $\begin{array}{c}\text { api/pari } \\
\text { wiata }\end{array}$ & tbl_pariw \\
tourist data & & isata \\
\hline \hline
\end{tabular}

\section{IV.RESULT AND DISCUSSION}

\section{Data Analysis}

Data analysis is done by carrying out research in detail, accurately and built based on the formulation of the problem based on the background of the problem, after collecting data, examining the existence of a problem by examining the existing problems more deeply in an issue to get a specific result and goal. . In developing the Samarinda City Tourism Geographic Information System web development, spatial data in the form of location coordinates and non-spatial data in the form of attribute data include tourist names, addresses, and types of tours, descriptions and pictures. 2. System Design

The following is the design of the Samarinda City Tourism Geographic Information System web creation system. This design makes it easier to plan the stages of web development for the Samarinda City Tourism Geographic Information System.

a) System Flowchart

In this case, the system requires internet and GPS, if the Internet and GPS on the user are active, it will proceed to the next stage, while if the user has not activated GPS and internet, it must be activated first. In this system, the user can immediately see a map of the distribution of tourist locations and continue to search for the tourist location that the user wants. If the user has entered the desired location, the system will start looking for tourist locations and the route to be taken. Users can use it, if they still want to find the desired tourist location, the user can return to the start menu or search for tourist locations. Can be seen in picture 14 .

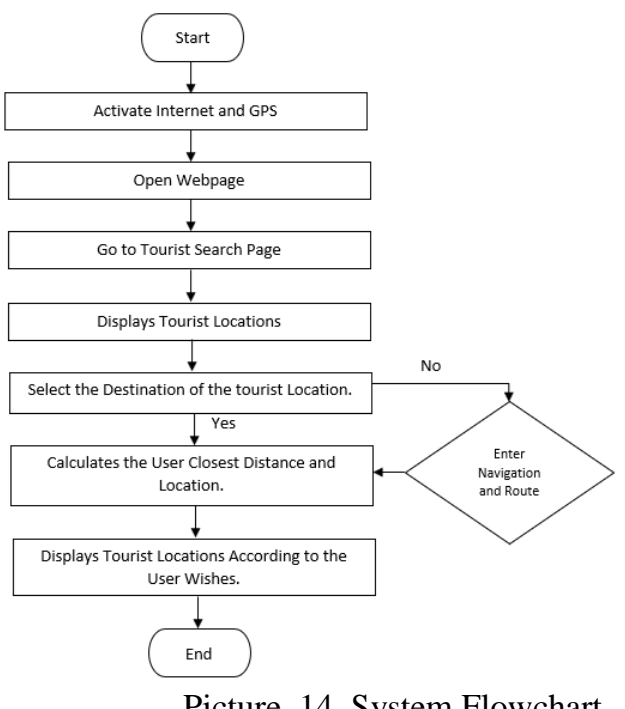

\section{b) Use Case Diagrams}

This diagram will describe the interaction between users on a system that shows how the system is used. This diagram provides an explanation that in this Web-GIS there are two actors, namely, the admin who has the task of managing tourist site pages, namely to add, delete, edit location data. , and manage tourist location information data. But before managing data. Admin is required to login to the system first. Furthermore, the actor user is showing the user to view the map information of the location of the tourist location, detecting the location (My Location), information about the tourist location, looking for the closest route to the tourist location. Can be seen in picture 15 . 


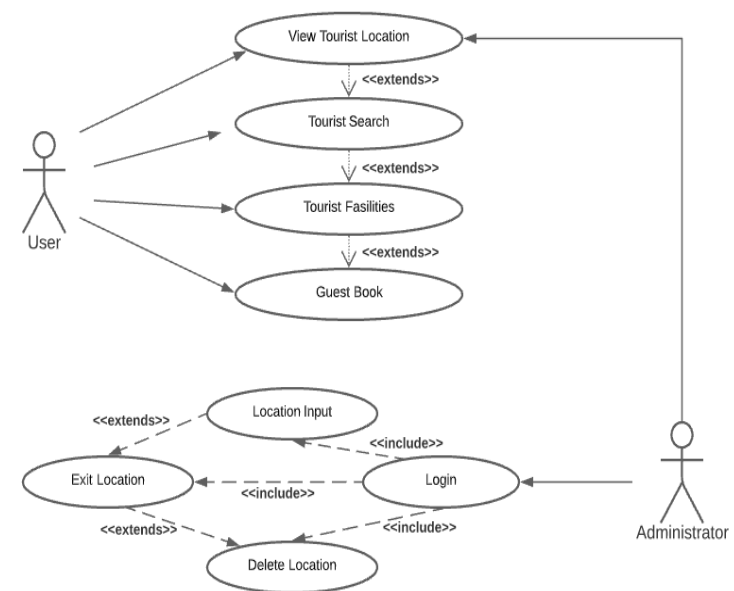

Picture. 15. Use Case Diagram

\section{c) Activity Diagrams}

In this Activity Diagram, the user opens the page and on the web page, the user can already see the tourism map in Samarinda City. The system will open a list of tours. Users can select the search menu or select the nearest tourist list and the system will immediately display. Next, the user selects the desired tourist location and the system will display the location. After that, the user selects navigation to go to the selected tourist location. And the system will display the route to the user's location. Can be seen in picture 16 .

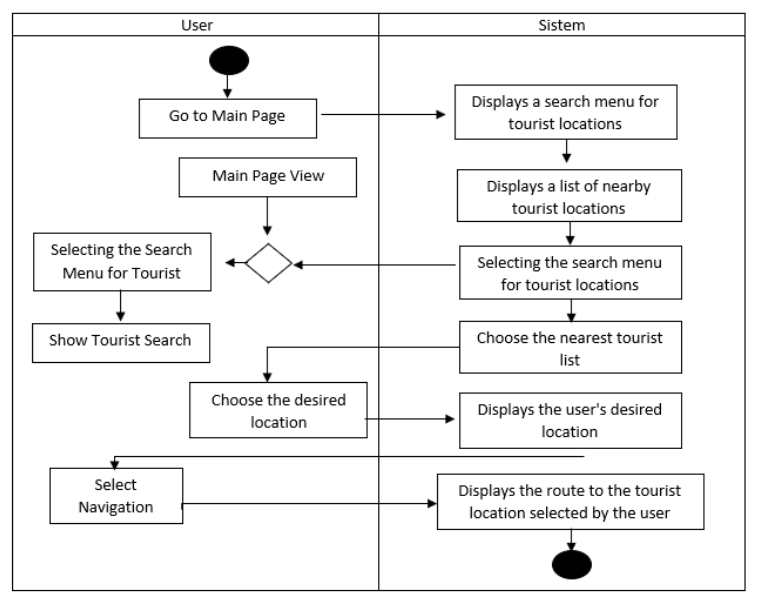

Picture. 16. Activity Diagram

\section{d) Sequence Diagrams}

In this sequence diagram is divided into 2, namely the admin sequence diagram and the user sequence diagram.

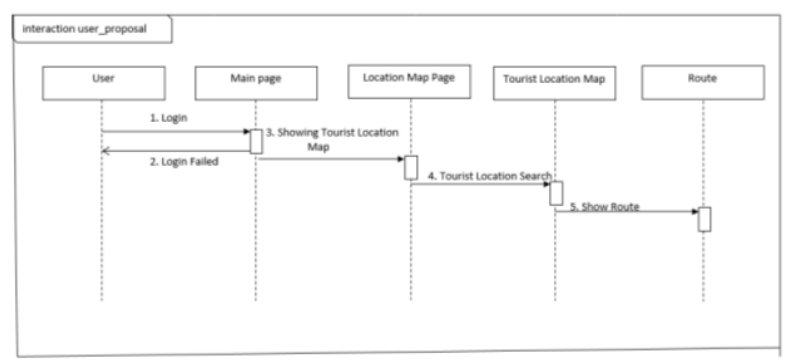

Picture. 17. Sequence Diagram User

\section{e) Class Diagrams}

Class diagrams describe the structure of the system in terms of defining the classes that will be created to build the system. Can be seen in picture 18 .

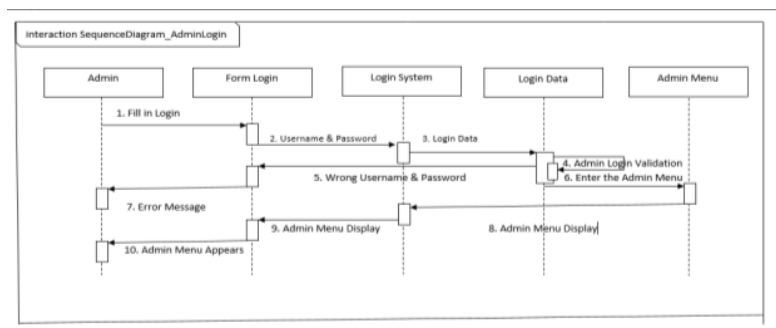

Picture. 18. Sequence Diagram Admin

\section{Samarinda City Tourism GIS Web Display}

The following is a display of the results of making the Samarinda City Tourism Geographic Information System web. This website was created in such a way as to support the dissemination of information on tourism in the city of Samarinda.

a. Login View

This page functions as a gateway that is directly connected to the database for admins to enter the website system. There are two forms on the login page, namely username and password which will be automatically saved into the database. Can be seen in picture 19 .

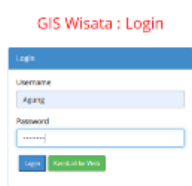

Picture. 19. Login Page

\section{b. Homepage}

This page serves as the main page after opening the website. There is some related information, tour lists and tourist details. Admin can also edit data after logging in on this page. Can be seen in picture 20 .

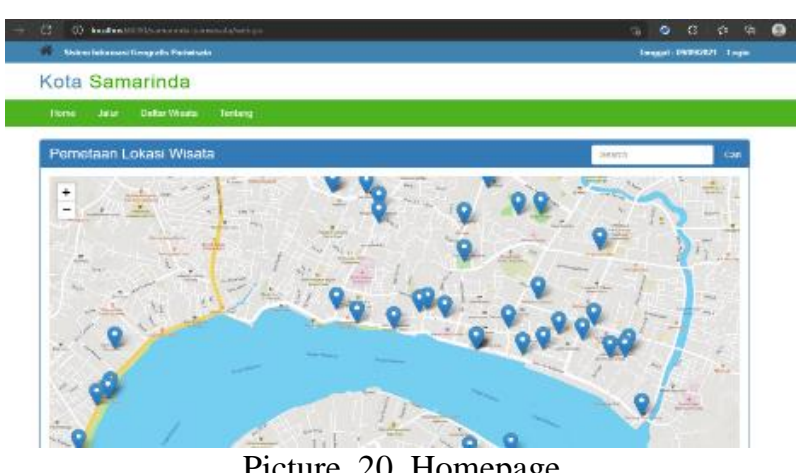

Picture. 20. Homepage 


\section{c. Path Page}

On the Paths page, users can find out the way to the selected tourist location by sliding the two points that have been provided. Can be seen in picture 21 .

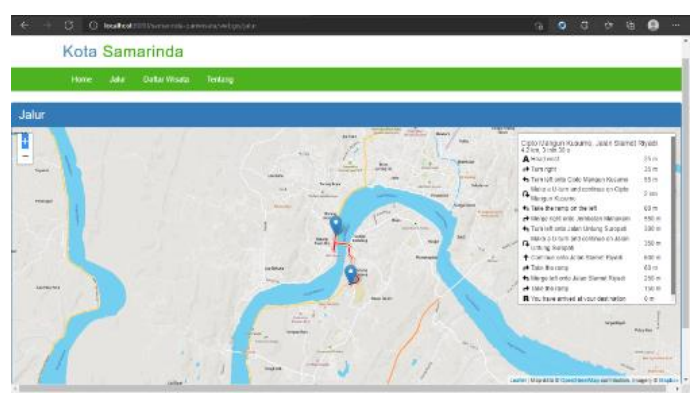

Picture. 21. Path Page

\section{d. Tourist Listing Page}

This page provides complete tourism information and is easy to understand. In this display there is information on the name of the tour, the address, the type of tour, description and pictures of the tour. Can be seen in picture 22 .

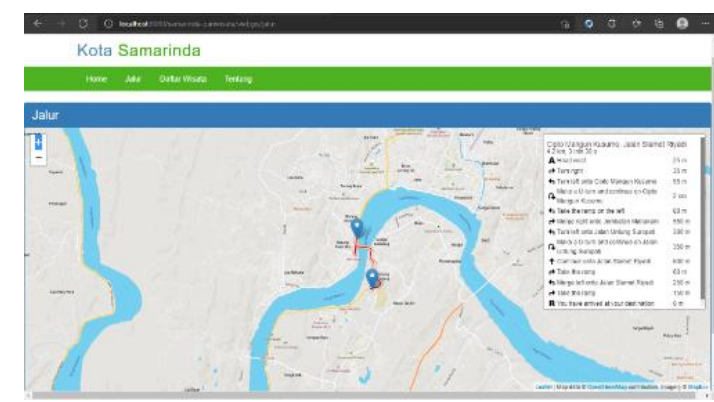

e. About Page

Picture. 22. Tourist list Page

This page contains information on the use of the city's tourism geographic information system. Can be seen in picture 23 .

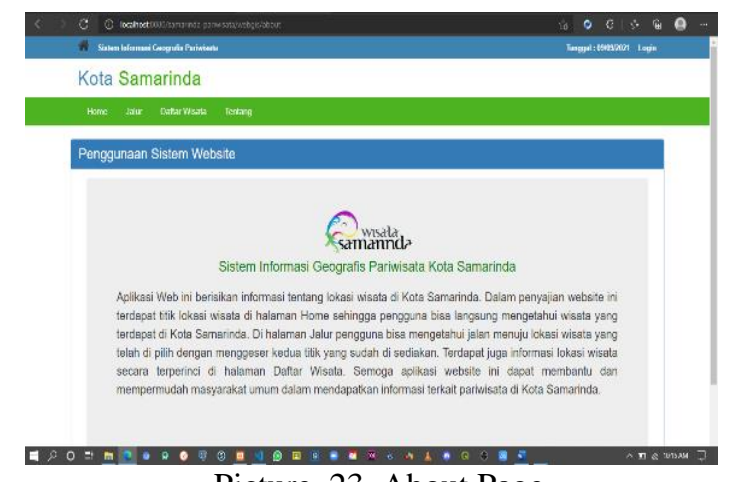

Picture. 23. About Page

\section{f. Tourist Details Page}

When we press the detail button found at the tourist point, the website will provide a more interesting display of information. Can be seen in picture 24.



Picture. 24. Tourist details Page

g. Mapping Page

On this page the admin can find out all the tourist points that have been added to the website. Can be seen in picture 25 .

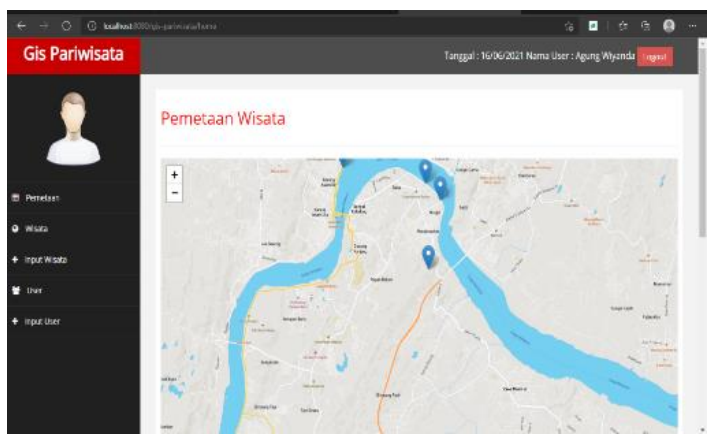

Picture. 25. Mapping Page

\section{h. Tourist Data}

On this page the admin can delete and change tourism information. Can be seen in picture 26 .

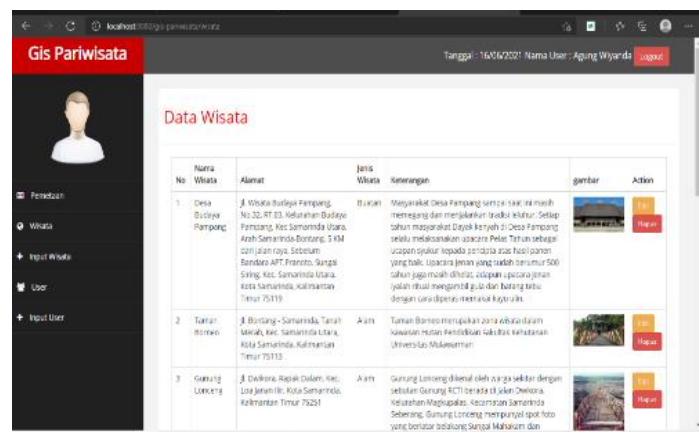

Picture. 26. Tourist Data

\section{i. Data Input Page}

The tourist data input page is used to add new tourist objects to the website. When adding a tourist attraction, the admin is required to fill out all the forms that have been provided. Can be seen in picture 27 .

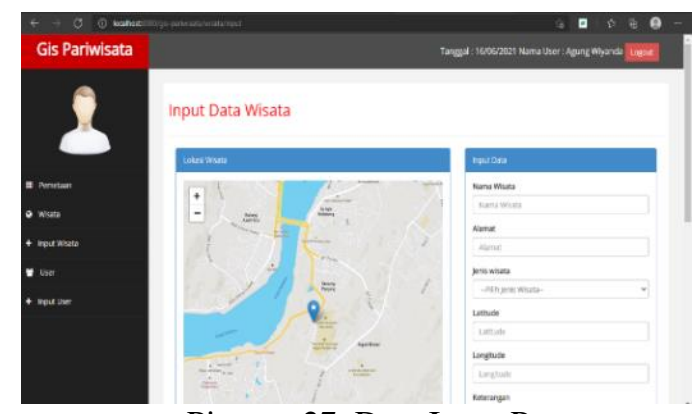

Picture. 27. Data Input Page 


\section{j. User Data Page}

On this page the admin can delete and change user information. Can be seen in picture 28 .

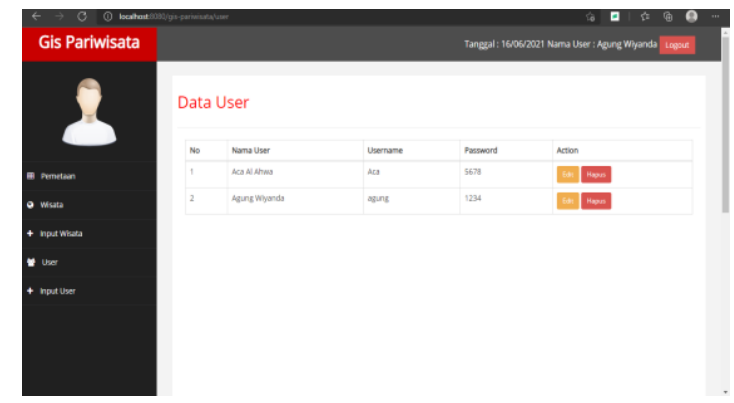

Picture. 28. User Data Edit Page

\section{k. User Data Input Page}

The user data input page is used to add new tourist objects to the website. When adding a tourist attraction, the admin is required to fill out all the forms that have been provided. Can be seen in picture 29 .

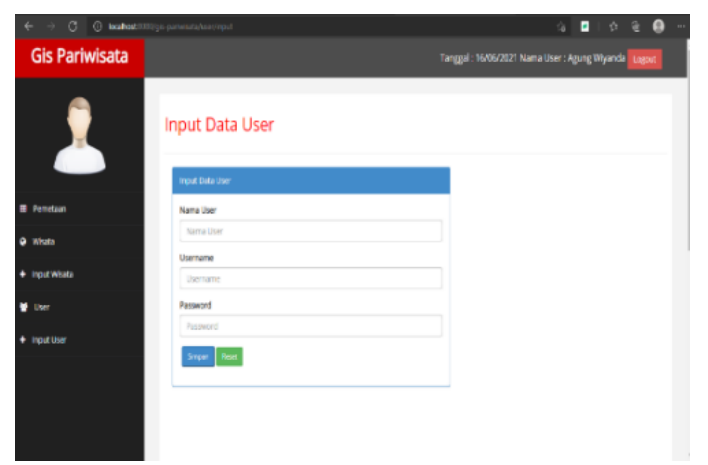

Picture. 29. User Data Input Page

\section{Samarinda City Tourism GIS Web API}

\section{a. API Get Travel Type data}

Picture 30 shows, the tourism type API with the GET method is an API that displays the recorded tourism information of the city of Samarinda.

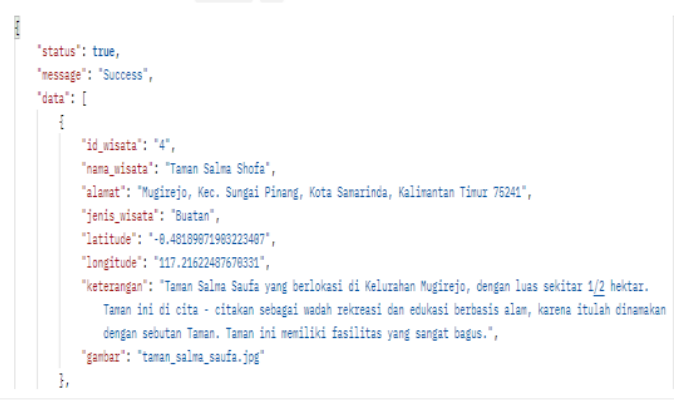

Picture. 30. Response Method GET Data Type

\section{b. API Post Data Type of Tour}

The type of tourism API with the POST method is an API that displays information on tourism in the city of Samarinda that has been successfully recorded, shown in Picture 31.



Picture. 31. Response Method POST Data Type

\section{System Test}

Testing this system is done by trying the functions that have been made on each page. Can be seen in table 4.

\begin{tabular}{|c|c|c|c|}
\hline $\begin{array}{l}\text { Tested } \\
\text { Case }\end{array}$ & $\begin{array}{l}\text { Expected } \\
\text { Results }\end{array}$ & Results Obtained & Result \\
\hline $\begin{array}{l}\text { Home } \\
\text { Button }\end{array}$ & $\begin{array}{l}\text { The system } \\
\text { can display } \\
\text { a map } \\
\text { along with } \\
\text { tourist } \\
\text { locations. }\end{array}$ & $\begin{array}{l}\text { After pressing } \\
\text { the button, a map } \\
\text { with location } \\
\text { points appears. }\end{array}$ & Success \\
\hline $\begin{array}{l}\text { Path } \\
\text { button } \\
\text { on } \\
\text { Webpa } \\
\text { ge }\end{array}$ & $\begin{array}{l}\text { The system } \\
\text { can display } \\
\text { a map with } \\
\text { paths / } \\
\text { routes. }\end{array}$ & $\begin{array}{l}\text { Once the button } \\
\text { is pressed, a map } \\
\text { with the } \\
\text { specified path } \\
\text { appears. }\end{array}$ & Success \\
\hline $\begin{array}{l}\text { Tourist } \\
\text { List } \\
\text { Button }\end{array}$ & $\begin{array}{l}\text { The system } \\
\text { can display } \\
\text { a list of } \\
\text { tourist. }\end{array}$ & $\begin{array}{l}\text { After the button } \\
\text { is pressed, a list } \\
\text { of tourist } \\
\text { locations } \\
\text { appears. }\end{array}$ & Success \\
\hline $\begin{array}{l}\text { About } \\
\text { Bottom }\end{array}$ & $\begin{array}{l}\text { The system } \\
\text { can display } \\
\text { website } \\
\text { usage } \\
\text { notification } \\
\text { s. }\end{array}$ & $\begin{array}{l}\text { Once the button } \\
\text { is pressed, a } \\
\text { website usage } \\
\text { notification } \\
\text { appears. }\end{array}$ & Success \\
\hline $\begin{array}{l}\text { Login } \\
\text { Bottom }\end{array}$ & $\begin{array}{l}\text { The system } \\
\text { can display } \\
\text { the login } \\
\text { form. }\end{array}$ & $\begin{array}{l}\text { After pressing } \\
\text { the button, the } \\
\text { login form } \\
\text { appears }\end{array}$ & Success \\
\hline
\end{tabular}

\section{Respondent Test}

Testing the results of the respondents there are 30 people consisting of several students, the general public and employees of the tourism office of the city of Samarinda. There are 10 questionnaire questions with answer choices, namely strongly agree (A), agree (B), Neutral (C), disagree (D) and strongly disagree (E). Can be seen in table 5 .

Table 5. Respondent Test Result

\begin{tabular}{|c|c|c|c|c|c|}
\hline \multirow[t]{2}{*}{ Question } & \multicolumn{5}{|c|}{ Number of Respondents } \\
\hline & $\mathrm{A}$ & $\mathrm{B}$ & $\mathrm{C}$ & $\mathrm{D}$ & $\mathrm{E}$ \\
\hline $\begin{array}{l}\text { I think I will use this system } \\
\text { again. }\end{array}$ & 9 & 18 & 2 & 1 & 0 \\
\hline $\begin{array}{l}\text { I find this system complicated to } \\
\text { use. }\end{array}$ & 0 & 0 & 9 & 17 & 4 \\
\hline I find this system easy to use. & 7 & 20 & 3 & 0 & 0 \\
\hline $\begin{array}{l}\text { I need help from someone else or } \\
\text { a technician in using this system. }\end{array}$ & 0 & 0 & 6 & 18 & 6 \\
\hline $\begin{array}{l}\text { I feel the features of this system } \\
\text { are working properly. }\end{array}$ & 9 & 15 & 6 & 0 & 0 \\
\hline $\begin{array}{l}\text { I feel there are a lot of things that } \\
\text { are inconsistent (incompatible on } \\
\text { this system). }\end{array}$ & 0 & 0 & 8 & 17 & 5 \\
\hline I feel like other people will & 7 & 22 & 1 & 0 & 0 \\
\hline
\end{tabular}


understand how to use this

system quickly.

I find this system confusing.

I feel there are no obstacles in

using this system.

I need to get used to it first

before using this system.

\section{Testing Samarinda City GIS Web Design}

Usability testing was conducted using the SUS (System Usability Scale) questionnaire. Table 6 shows, from the data obtained from the SUS questionnaire, calculations were then carried out according to the procedures in the SUS data analysis.

Respondent
R1
R2
R3
R4
R5
R6
R7
R8
R9
R10
R11
R12
R13
R14
R15
R16
R17
R18
R19
R20
R21
R22
R23
R24
R25
R26
R27
R28
R29
R30

Table 6. Questionnaire data Result

$\begin{array}{llllllllll}\text { Q3 } & \text { Q4 } & \text { Q5 } & \text { Q6 } & \text { Q7 } & \text { Q8 } & \text { Q9 } & \text { Q10 } & \text { Total } & \text { SUS Score } \\ 3 & 4 & 3 & 3 & 4 & 4 & 4 & 4 & 36 & 90.0 \\ 3 & 2 & 4 & 2 & 4 & 2 & 3 & 2 & 28 & 70.0 \\ 4 & 3 & 2 & 3 & 4 & 3 & 4 & 3 & 33 & 82.5 \\ 2 & 2 & 4 & 3 & 3 & 2 & 3 & 2 & 25 & 62.5 \\ 2 & 3 & 4 & 3 & 3 & 3 & 3 & 3 & 31 & 77.5 \\ 4 & 3 & 3 & 4 & 4 & 3 & 4 & 3 & 35 & 87.5 \\ 3 & 3 & 4 & 3 & 4 & 3 & 4 & 3 & 34 & 85.0 \\ 4 & 3 & 4 & 2 & 4 & 3 & 4 & 3 & 34 & 85.0 \\ 3 & 3 & 3 & 2 & 3 & 3 & 3 & 3 & 27 & 67.5 \\ 3 & 2 & 3 & 3 & 3 & 2 & 3 & 2 & 26 & 65.0 \\ 3 & 3 & 3 & 2 & 3 & 3 & 3 & 3 & 29 & 72.5 \\ 3 & 3 & 2 & 2 & 3 & 3 & 2 & 3 & 27 & 67.5 \\ 4 & 4 & 2 & 4 & 4 & 4 & 4 & 4 & 38 & 95.0 \\ 3 & 3 & 3 & 3 & 3 & 3 & 3 & 3 & 30 & 75.0 \\ 3 & 3 & 3 & 3 & 3 & 3 & 3 & 3 & 30 & 75.0 \\ 3 & 4 & 2 & 4 & 3 & 4 & 3 & 4 & 34 & 85.0 \\ 4 & 3 & 3 & 3 & 3 & 3 & 3 & 3 & 31 & 77.5 \\ 4 & 3 & 4 & 4 & 3 & 3 & 3 & 3 & 33 & 82.5 \\ 3 & 2 & 3 & 3 & 3 & 2 & 2 & 2 & 25 & 62.5 \\ 3 & 3 & 2 & 3 & 3 & 3 & 2 & 3 & 28 & 70.0 \\ 3 & 4 & 3 & 2 & 3 & 2 & 3 & 3 & 28 & 70.0 \\ 4 & 3 & 4 & 3 & 3 & 3 & 3 & 3 & 33 & 82.5 \\ 3 & 3 & 3 & 3 & 3 & 3 & 3 & 4 & 31 & 77.5 \\ 3 & 4 & 3 & 2 & 3 & 2 & 2 & 3 & 27 & 67.5 \\ 3 & 3 & 2 & 3 & 3 & 4 & 3 & 2 & 31 & 77.5 \\ 3 & 2 & 3 & 4 & 3 & 3 & 3 & 3 & 29 & 72.5 \\ 3 & 4 & 3 & 3 & 3 & 2 & 3 & 3 & 29 & 72.5 \\ 3 & 3 & 3 & 2 & 3 & 3 & 3 & 3 & 29 & 72.5 \\ 2 & 2 & 4 & 3 & 2 & 3 & 3 & 4 & 29 & 72.5 \\ 3 & 3 & 4 & 3 & 3 & 3 & 1 & 3 & 27 & 67.5 \\ & \text { Average Score } & & & & & & 75.02 \\ & & & & & & & & & \end{array}$

After calculating the data from the respondents, a calculation is made for each number of questions multiplied by 2.5 then the calculation of the average value of the SUS score is 75.02. Referring to the basis of the SUS score assessment, this proves that the web test of the Samarinda City Tourism Geographic Information System has a good predicate.

8. Use of the Samarinda City Tourism GIS Website

Users open the home page on the Samarinda City Tourism Geographic Information System website, the page displays information on the distribution of tourism location points and users can search for tourism locations in the search column that has been provided. On the path page there are two points as markers to find out the way to the selected tourist location by specifying the location of the user point and the point of the destination tourist location. On the tourist list page, users can see a list of tours based on tour names, addresses, types of tours, descriptions and pictures. Already able to see the existing tourism map in Samarinda City. On the about page, users can find out about using the Samarinda City Tourism Geographic Information System website.

9. API Get Tour Type data

In building a Geographic Information System for Tourism in the City of Samarinda based on Android, it is necessary to collect data on the types of tourism contained in the website database of the Geographical Information System for Tourism in the City of Samarinda in order to display data on types of tourism. By using the Get method, users can call up data on the tourism type table as a whole or based on criteria.

\section{CONCLUSION}

Samarinda City Tourism Geographic Information System Web was successfully created with the Code Igniter framework where on the home page it can display tourist location points, so tourists can immediately know the tourist location points in the city. Samarinda. On the path page the user can find out the road / route to the tourist location. There is also detailed tourist information on the tour list page and on the about page displaying information on the use of the Samarinda City Tourism Geographic Information System. The tourism API successfully displays and adds data based on tourist names, addresses, and types of tours, latitude, longitude, descriptions and images. 


\section{REFERENCE}

Ambarita, Umagapi, D., dan Arisandy. 2018. Sistem Informasi Geografis Wisata Bahari pada Dinas Pariwisata Kota Ternate. Jurnal Ilmu Komputer dan Informatika. Volume 1. 59 - 69. Maluku Utara.

Amrin, M. 2015.Penggunaan Sistem Informasi Geografis Menumbuhkan Keinginan Perjalanan Wisata. Jurnal Ipteks Terapan. Vol 9. 98. Padang.

Ardhiyani, Mulyono, R. P., dan Herry. 2018. Informasi Pariwisata Berbasis Web Sebagai Media Promosi Pada Kabupaten Tebo. Jurnal Manajemen Sistem Informasi. Vol.3. 952-972. Jambi.

Indrajit, R. E. 2015. Manajemen Sistem Informasi dan Teknologi Informasi. Stimik Perbanas Renaissance Center. Jakarta.

Kurnia, R. 2015. Pengembangan Pariwisata oleh Dinas Kebudayaan dan Pariwisata (DISBUDPAR) Kota Bukittinggi untuk Meningkatkan Pendapatan Asli Daerah (PAD). scholar.unand.ac.id. Padang.

Qolis, N., dan Farriza, A. 2009. Pemetaan dan Analisa Sebaran Sekolah Untuk Peningkatan Layanan Pendidikan di Kabupaten Kediri dengan GIS. Jurnal Teknik Informatika. 1-5. Surabaya

Rani Susanto, A. D. 2016. Perbandingan Model Waterfall Dan Prototyping Untuk Pengembangan Sistem Informasi. Majalah Ilmiah Unikom. 14. 41. Bandung.

Renaldi, R., dan Anggoro, D. 2020. Sistem Informasi Geografis Pemetaan Sekolah Menengah Atas atau Sederajat di Kota Surakarta Menggunakan Leaflet Javascript Library Berbasis Website. Jurnal Teknik Elektro. 20. 109-116. Surakarta.

Schollmeyer, M. 2015. GPS Essentials. Retrieved from Manual: http://www.gpsessentials.com

Sihombing, A. W. 2020. Sistem Informasi Pariwisata Berbasis Web Kabupaten Dairi. http://repositori.usu.ac.id. Sumatera Utara.

Suntoyo, M. 2012. Sistem Informasi Geografis Berbasis Web Pemetaan Potensi Panas Bumi di Indonesia Menggunakan Google Maps. Jurnal Dasi. Vol 16. 60. Yogyakarta.

Susilo, F. D. 2018. Perancangan dan Evaluasi User Interface Aplikasi Smart Grid Berbasis Mobile Application. JNTETI. 7. 155. 